\title{
The Lyrical Art of Ana Cristina Cesar
}

\section{Antonio Donizeti da Cruz1[0000-0002-4672-7542] and Dhandara Capitani ${ }^{1}$}

${ }^{1}$ Western Paraná State University - Unioeste, Cascavel PR, Brazil

https://doi.org/10.33847/2712-8148.1.13

\begin{abstract}
Ana Cristina Cesar is one of the great poets of the 1970s and 80 s in Brazil. In this paper, some of her poems are analyzed in the perspective of how her lyrical narrative presents an interactive dialogue with the reader and criticizes modernity. Ana Cristina Cesar's poetic work privileges critical-reflexive language, the theme of identity, alterity, lyrical memory, poetic synthesis, and questioning, as marks of modernity. The word-memory is the essential factor that moves the aspirations and feelings of poetic self, because at the moment of reminiscing, the self recollects, in depth, the events and experiences previously experienced. The word is a force that drives the Word Artist to realize dreams, goals, and achievements. Through the poetic word, the poem develops the continuous transmutation of language, generating new possibilities of being and effecting poetic procedures through the lyrical genres, centered in the articulations of the poetic creation. The poetic craft is essentially of creating oneself, thus poetry being also self-creation, knowledge, and transmutation.
\end{abstract}

Keywords: Brazilian Poetry, Lyrical Analysis, Poetic Craft.

\section{Ana Cristina Cesar and her poetic craft}

\subsection{Ana $C$. and her background}

Ana Cristina Cesar (or Ana C., as she used to sign her works) was one of the main authors of the Brazilian "mimeograph generation", which appeared in Brazil in the 1970 s and 80 s. Such epithet refers to the technology available to these marginal artis-tis at the time, to reproduce their work on a scale and thus disseminate it. Ana C. was a poet truly in contact with her historical moment, discussing, in her critical texts, the issue of political transgression and how the context of the military dictatorship influenced artists in finding their own voices.

ANA CRISTINA CESAR was born in Rio de Janeiro, in June 1952. She published her first poems early in life, in 1959, in the "Suplemento Literário", of the Rio de Janeiro's newspaper Tribuna da Imprensa. In 1975 she got her degree in Letters from the Pontifical Catholic University (PUC) of Rio de Janeiro, and her Master in Communication from the School of Communication of the Federal University of Rio de Janeiro in 1979. In the following year, she achieved her title of Master of Arts (MA) in Theory and Practice of Literary Translation from the University from Essex, England, translating the short story Bliss, by Katherine Mansfield. She practiced intense journalistic and editorial activities and as a translator of relevant foreign authors, including the poet Sylvia Plath. He translated several works, among them, "The Hite Re-port: a profound study on female sexuality", by Shere Hite, as well as wrote several literary and journalistic essays.

Ana Cristina Cesar published the following works: Luvas de pelica; Cenas de abril; Correspondência completa; Literatura não é documento. In 1982, he published A teus pés. After her death, on October 29, 1983, the gathering of some her unpublished writings resulted in compilations organized by Armando Freitas Filho, such as: Inéditos e dispersos (prose and poetry) (1985); Escritos da Inglaterra (1988), Escritos no Rio (1993) and Crítica e Tradução (1999); and in the most recent 
collection, of her assorted texts and drafts, Antigos e Soltos (2008), organized by Viviana Bosi.
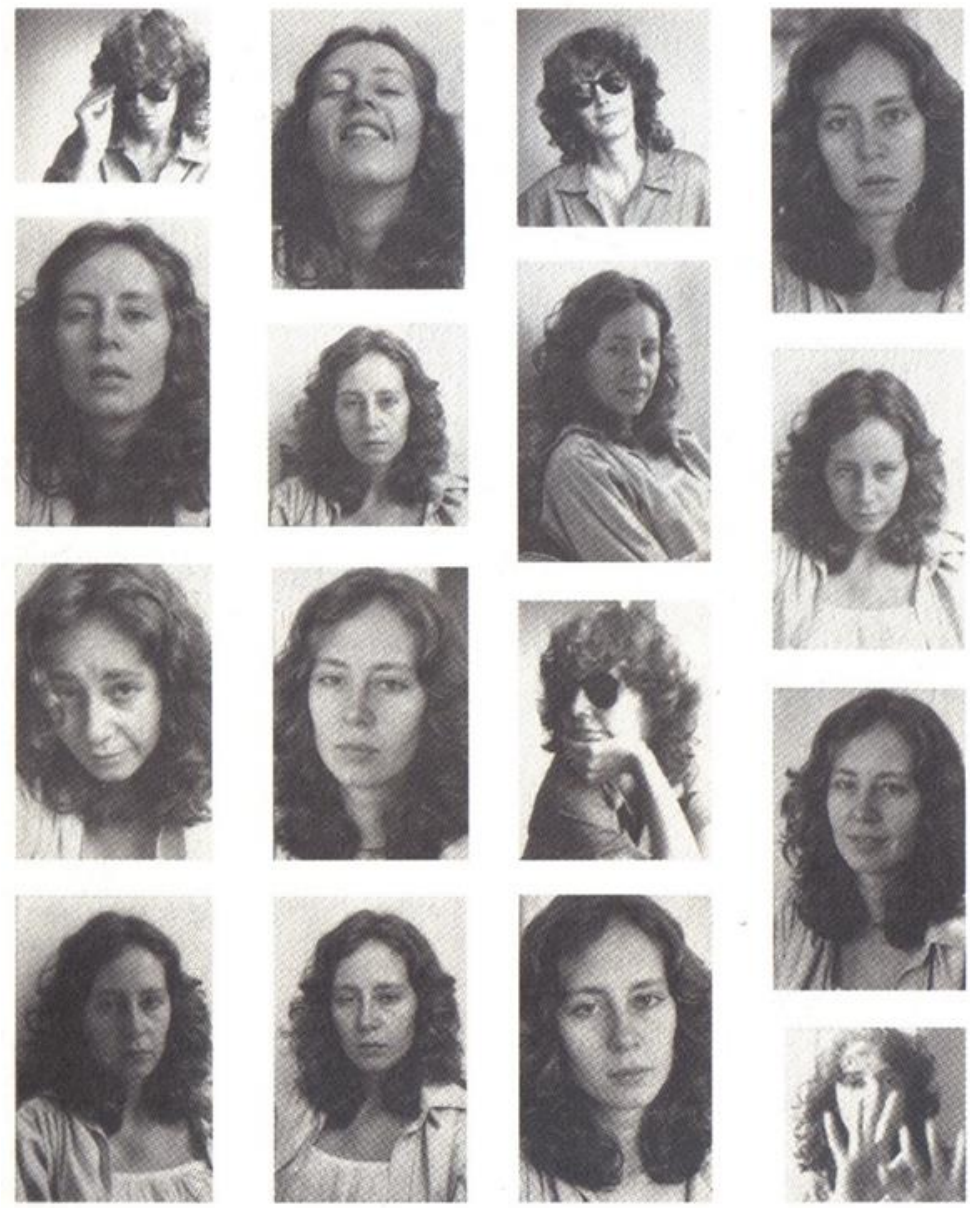

Fig. 1. Collage of pictures of Ana Cristina Cesar [1].

\subsection{Lyrism and enchantment in language}

Ana Cristina Cesar's texts register the subtleties of a poetic craft based on the strength of language, memory, and the realization of a voice that points to clear visual images, moments of attentive observation of a self in touch with their world.

In the work of the poet-artist Ana Cristina Cesar, there is a remarkable intertwining of poetic images centered on the question of identity/alterity and on the language imprinted by the content of modernity and criticism, as in the concise text, in prose:

"Lá onde cruzo com a modernidade, e meu pensamento passa como um raio, a pedra no caminho é o time que você tira de campo ${ }^{1 "}$. [1]

According to Armando Freitas Filho, "Ana Cristina Cesar looked in the face of modernity. Perhaps that is why she died early - pure permanent passage - many wings and some disdain for what could be root. The place she occupies is on the

\footnotetext{
1 Translated by the authors: "There where I cross with modernity, and my thought cuts like a lightning, the stone in the path is the team that you bench."
}

(CICS. Journal of Digital Art \& Humanities, Vol.1, Iss. 1, Oct 2020 
horizon - virtual and fast". Commenting on the poetry of Ana Cristina Cesar, poet Armando Freitas Filho asserts:

Her verse, which belonged to the educated side of the generation that appeared in the 1970s, is today a touchstone for all poetry that wants to be new; with her stylized motifs and tones that are accompanied, in the background, by a sudden and unusual melody that seems to have been made by the mixture of crystals, heavy metal, and taffeta. The work is brief, as if essential cinema, and quick. She died of thirst in the midst of so much silk. We never forgot her passion, burning, and drought. Which burns hotter: the ice stone or the red-hot iron? Snow volcano. She wasn't she gets - wild $^{2}$. [2]

In the text "Soneto", the poet Ana Cristina introduces herself and seeks dialogue with the reader through some language game. She also designs a possible intertextual reference to the poem "Autopsicografia", by Fernando Pessoa, which states "The poet is a pretender" (from Latin Fingire: imitatore: forger or pretender):

\section{Soneto}

Pergunto aqui se sou louca

Quem quem saberá dizer

Pergunto mais, se sou sã

E ainda mais, se sou eu

Que uso o viés pra amar

E finjo fingir que finjo

Adorar o fingimento

Fingindo que sou fingida

Pergunto aqui meus senhores

Quem é a loura donzela

Que se chama Ana Cristina

E que se diz ser alguém

É um fenômeno mor

Ou um lapso sutil?

inconfissões $-31.10 .68^{3}[1]$

There are several questions about the lyrical self: there are questions about the Self and about language. Note the absence of punctuation in the text, except for the last verse in which the question mark appears, giving it accentuated importance. The permanent questioning - a profound mark of modern literature - revolves around the absence represented by the color white of the blank page. So, it is through words that the poet develops the continuous transmutation of language, generating new

\footnotetext{
2 Original text: "Seu verso, que pertenceu à vertente cultivada da geração que apareceu em 70 , é, hoje, pedra de toque para toda poesia que se quer nova; com seus motivos e matizes estilizadas que se deixam acompanhar, ao fundo, por uma brusca e inusitada melodia que parece ter sido feita pela mistura de cristais, heavy metal e tafetá. A obra é breve, um cinema essencial, e depressa. Morria de sede no meio de tanta seda. Nunca nos esquecemos de sua paixão acesa e seca. O que mais queima: a pedra de gelo ou o ferro em brasa? Vulcão de neve. Ela não foi - ela fica - como uma fera", translated by the authors.

3 Translated by the authors: Sonnet // I ask here if I'm crazy/ Who can tell/ I ask more, if I am sane/ And even more, if I'm me// Who uses the bias to love/ And pretend to pretend that I pretend/ Adoring the pretending/ Pretending I'm pretending// I ask here, gentlemen/ Who is the blonde maiden/ Who goes by the name Ana Cristina// And who is said to be someone/ It is a major phenomenon/ Or a subtle lapse?// inconfessions - 10.31.68
} 
possibilities of being and also of implementing poetic procedures through the genres of lyric, in prose and verse, centered on the articulations of the poetic language, as states the lyrical self in the verses of the poem:

\title{
Primeira Lição
}

Os gêneros de poesia são: lírico, satírico, didático, épico, ligeiro.

O gênero lírico compreende o lirismo.

Lirismo é a tradução de um sentimento subjetivo, sincero e pessoal.

É a linguagem do coração, do amor.

O lirismo é assim denominado porque em outros tempos os versos sentimentais eram declamados ao som da lira.

O lirismo pode ser:

a) Elegíaco, quando trata de assuntos tristes, quase sempre a morte.

b)Bucólico, quando versa sobre assuntos campestres.

c) Erótico, quando versa sobre o amor. epicédio.

O lirismo elegíaco compreende a elegia, a nênia, a endecha, o epitáfio e o

Elegia é uma poesia que trata de assuntos tristes.

Nênia é uma poesia em homenagem a uma pessoa morta.

Era declamada junto à fogueira onde o cadáver era incinerado.

Endecha é uma poesia que revela as dores do coração.

Epitáfio é um pequeno verso gravado em pedras tumulares.

Epicédio é uma poesia onde o poeta relata a vida de uma pessoa morta. ${ }^{4}$

Poetry, as a search for meaning, makes the poet and the reader maintain an inquiring spirit before this art, since, in the words of Octavio Paz, in modern times, the poem acquires the form of questioning and, at the same time, is "recovery of otherness, projection of language in a space depopulated by all mythologies, the poem takes the form of interrogation. It is not the man who asks: it is language that inquires us". In Ana Cristina Cesar's prose and poetry, the words often acquire the inflection of an ontological interrogation, as in the verses of the following poem, marked by the heterogeneities of being and worldview, transmuted into poetic language:

\section{Como rasurar a paisagem}

\author{
a fotografia \\ é um tempo morto \\ fictício retorno à simetria \\ secreto desejo do poema \\ censura impossível \\ do poeta ${ }^{5}[1]$
}

Among the poet's arts and crafts, the search for the desire-words of the lyrical self to register "the scratches", the cracks, the interdictions and thoughts connected to the construction of the poem and in the way of expressing the desires of a poetic

\footnotetext{
4 Translated by the authors: First lesson// The genres of poetry are: lyrical, satirical, didactic, epic, light./ The lyrical genre comprises lyricism./ Lyricism is the translation of a subjective, sincere and personal./ It is the language of the heart, of love./ Lyricism is so named because in other times sentimental verses were recited by the sound of the lyre./ Lyricism can be:/ a) Elegiac, when dealing with sad matters, almost always death./ b) Bucolic, when dealing with pastoral themes./ c) Erotic, when it is about love./ Elegiac lyricism comprises elegy, dirge, lament, epitaph and the epicedium./ Elegy is poetry that deals with sad subjects./ Dirge is poetry in homage to a dead person./ It was recited by the fire where the corpse was incinerated./ Lament is a poetry that reveals the pains of the heart./ Epitaph is a brief verse engraved on tombstones./ Epicedium is a poetry where the poet recounts the life of a dead person.

5 Translated by the authors: How to scratch the landscape// photograph/ is time dead/ fictitious return to symmetry// secret wish of the poem/ impossible censorship/ of the poet
}

CICS. Journal of Digital Art \& Humanities, Vol.1, Iss. 1, Oct 2020 
craft that refers to the articulations from the lyric directed to introspection by the language operators and by the readers as well. The uniqueness of poetry in Ana Cristina Cesar's poetry arises not only from the poet's ideas or attitudes, but above all from her voice, that is, she turns the poem into an act. This poetic doing is essentially "inventing oneself", hence poetry is also self-creation, knowledge, and transmutation of poetic language. According to Bachelard, such invention, or "conception", can be understood as the creation based on "dreaming meditation that builds a world by excavating the impressions of a dreamer's loneliness", which also appears in the following poem:

\section{estou atrás}

do despojamento mais inteiro
da simplicidade mais erma
da palavra mais recém-nascida
do inteiro mais despojado
do ermo mais simples
do nascimento a mais da palavra
$28.5 .69^{6}$

In this piece, the poetic self is searching for the most essential "word": the loniest simplicity, most utter detachment, more stripped-down entirety, simplest desert. In simplicity, wholeness. The choice of the word "wholeness" can be related to Jung's study, which postulates: "Wholeness is, therefore, empirically an immeasurable dimension, older and younger than consciousness involving it in time and space". In this sense, such totality involves consciousness in time and space, transcending both.

The most curious thing is to discover, in the literary text, the triple sequence removal, rapture, rebirth - that marked the mythical narratives, sequences that today designate the path followed in the creation of a work of art, the word "creation" in its utter sense, since it refers less to the production of the work than to its author transformed into another, modified. Through the transformation of the word, the transformative understanding of the self, that is, the "euphemistical transformation of the world", the creating imagination.

In the prose poem "aí é que são elas", one can note the incessant search for the lyrical self "looking for the keys", both in (self) referentiality, in the incessant search for identity, and in the paths and labyrinths of language marked by memories and forgetfulness, but, above all, it shows the lyrical memory registered by the words of the subject of the enunciation.

[...]

Eu procurava as chaves, a questão pendente, atravessava a luz deserta da praia de cabo a rabo, de vestido, voltava sobre os

meus próprios passos, ficava na varanda, atravessava os dias como uma planta perdida no deserto, naquele sol mais quieta. "Aqui eu

te conheço". Eu não sabia que sabia, aquela planta.

A pauta se calasse... Ouvia: "se você dançar..." Só de memória me espanto, de cabeça caio e saio, de cor, e pronto, socorram-me

\footnotetext{
6 Translated by the authors: I'm in search// of the most utter detachment/ of the loniest simplicity/ of the most newborn word/of the most detached wholeness/ of the simplest desert/ of one more birth of word/ 28.5.69
}

(CICS. Journal of Digital Art \& Humanities, Vol.1, Iss. 1, Oct 2020 
então nesse esforço de raízes, ouvindo a chuva nas telhas de menos dessa casa escura, com goteiras de verão e falta dágua, sem transporte, descendo a estrada de pó nas sandálias havaianas, fazendo uma bolha no calor, um lanho rubro, repetindo. "Ana, na janela há um recadinho", um curativo aberto, um sanduíche aberto, um fantasma romântico no peito,

"se você dançar..."

Me lembro da rádio a mil dentro do carro, e de uma saudade inata. ${ }^{7}[1]$

The lyrical narrative presents a "fast", telegraphic language, interspersed with a multiplicity of interconnected voices, marked by the strong accent of other voices that intersect the speech of the enunciating poetic self, who repeats "I was looking for the keys". The image of the lyrical subject is compared to a "plant lost in the desert". The text is guided by the search for the self in the face of desertification, the feeling of emptiness and an "innate longing".

In literary creation, Ana Cristina Cesar (re)invents worlds and gives various forms of meaning to life through words. In this sense, the word-memory is the essential factor that propels the aspirations and feelings of the poetic self, since it is the moment of deep reminiscing when the poetic voice relives previous events and experiences. This is well represented in the poem "Não, a poesia não pode esperar":

Não, a poesia não pode esperar.

O brigue toca as terras geladas do extremo sul.

Escapo no automóvel aos guinchos.

Hoje - você sabe disso? Sabe de hoje? Sabe que quando

digo hoje, falo precisamente deste extremo ríspido,

deste ponto que parece último possível?

A garganta sai remota,

longe de ti mal creio que te amo,

Corto o trânsito e resvalo

Que lugar ocupa este desejo de frutas?

Esta é a primeira folha aberta

$15.07 .83 .8[1]$

The intense rhythm of various images representing a modern and busy life creates an atmosphere of rush around, with the poetic self being evolved in revolving questions, concerned with creating and designing the poetic language, questioning the "love" she "hardly believes" that feels, interposing profound emotional questioning with the speedy velocity of daily routine.

\footnotetext{
7 Translated by the authors: I was looking for the keys, the pending question crossed the deserted light of the beach from top to bottom, in a dress, returning over the same path, lingered on the porch, spent the days like a plant lost in the desert, in that sun, most quiet. "Here I know you". I didn't know that I knew, that plant./ The agenda would shut up ... I could hear: "if you dance ..." Just from the memory I am astonished, from memory I fall and leave, by heart, and, done, help me then in this effort of roots, hearing the rain on the tiles of less than this dark house, with summer leaks and lack of water, without transportation, down the powdery road in flip-flops, making a bubble in the heat, a red flame,/ repeating. "Ana, there is a little note on the window", an open bandage, an open sandwich, a romantic ghost in the chest, "if you dance ..."/ I remember the radio raging in my car,/ and an innate longing.

${ }^{8}$ Translated by the authors: No, poetry cannot wait. / The brig touches the icy lands of the extreme South./ I escape in the automobile with squeaks./ Today - do you know that? Do you know today? Do you know that when/ I say today, I speak precisely of this harsh extreme,/ from this point that seems the last possible?// The throat turns remote,/ far from you I hardly believe I love you,/ I cut traffic and slip// What place does this desire for fruit occupy?// This is the first open sheet// 07.15.83.
}

(CICS. Journal of Digital Art \& Humanities, Vol.1, Iss. 1, Oct 2020 
Ana Cristina Cesar's work presents an incessant search to tell the world and (re)invent poetic language from an aesthetic and creative literary elaboration, with her "brushstrokes of poetry", in a multiplicity of themes: language, alterity, metapoetry, lyricism, passion, rapture - but above all, deep love for words and poetry, just like in the verses of the poem:

\section{Poema óbvio}

Não sou idêntica a mim mesmo sou e não sou ao mesmo tempo, no mesmo lugar e sob

Não sou divina, não tenho causa [o mesmo ponto de vista

Não tenho razão de ser nem finalidade própria:

Sou a própria lógica circundante

Junho/699 $[1]$

From denial to affirmation, a path that is present in the female discourse both in the "logic" that involves the lyrical subject, and in the perception of identity. These are verses marked by a sort of language play which shows presence versus absence. Note how every verse but the very last is a negative sentence. The duality "being" vs. "not-being" guides the poem. There is, in the text, the designing of word play and the profound theme of the unfolding of the self.

Through the poetic universe, the voice of the poem is based on the playful, rhythmic, and imaginary aspects of language, whose poetic function works as a constitutive vector of human nature - a word that is placed on the expressive plane superior to the non-signification of the natural order, since it is, as nucleus of dispersion and convergence, able to name the world. Ana Cristina Cesar's poetry is a power capable of giving meaning to life, that is, in seeking the essence of language, the Poet realizes the magic power using words for mediation, communication, and exercise of designing of various meanings.

For Ana C., the construction of the poetic text meant an intellectual process. In one of her essays on poetry, she states: "art implies work, aesthetic elaboration [...]"; "It is in this intervention carried out by the artist that his literary interest lies, and not in the fidelity of the 'transposition' of a certain reality to the literary." [11]. In all of her published texts, in life and posthumously, Ana Cristina always demonstrates the understanding that literary craft as arduous design.

\section{Final thoughts}

Ana Cristina Cesar was one of the foremost poets of the marginal poetry in Brazil. However, her deliberated and profoundly designed craft makes her poetic body of work transcend such limitations. She was in contact with her historical context, but that did not limit her work as only historically relevant. Her poetry is deeper and goes further.

The singularity in Ana Cristina Cesar's poetry yields not only from her expressed and represented ideas or attitudes, but above all from her voice, that is, how her poetic craft is essentially "inventing oneself". Thus, the process of carefully designing

\footnotetext{
${ }^{9}$ Translated by the authors: Obvious poem// I'm not identical with myself/ I am and am not at the same time, in the same place and under the same point of view/ I'm not divine, I am without cause/ I have no reason to be or own purpose:/ I am the surrounding logic itself// June/69
}

(CICS. Journal of Digital Art \& Humanities, Vol.1, Iss. 1, Oct 2020 
poetry is at once a craft of self-creation, creation of knowledge, and transmutation of poetic language.

Therefore, it is no surprise how the prose and poetry texts by Ana Cristina Cesar, cut in the chisel of memory, establish a poetic procedure in which the poetic word - as magic and enchantment - has the power to awaken in the reader an attention turned to the simplest, most sensitive things, because language is a sign of life and permanence.

\section{References}

1. Cesar, A. C. Inéditos e Dispersos: poesia/prosa. Ática, São Paulo (1998).

2. Freitas Filho, A. Apresentação da obra. In: Cesar, A. C. Inéditos e Dispersos: poesia/prosa. Ática, São Paulo (1998).

3. Cesar, A. C. A teus pés: prosa/poesia. Ática, São Paulo (1998).

4. Paz, O. O arco e a lira. Nova Fronteira, Rio de Janeiro (1982).

5. Bachelard, G. O Direito de Sonhar. 4th edn. Bertrand Brasil, São Paulo (1994).

6. Cesar, A. C. Poética. Companhia das Letras, São Paulo (2016).

7. Jung, C. G. Os Arquétipos e o Inconsciente Coletivo. Vozes, Perrópolis (2000).

8. Bilen, M. Comportamento Mítico-Poético. In: Brunel, P. (Org.). Dicionário de mitos literários. José Olympio, Rio de Janeiro (1998).

9. Durand, G. As Estruturas Antropológicas do Imaginário. Martins Fontes, São Paulo (2001).

10. Gonzáles, J. El cuerpo y la letra: la cosmología poética de Octavio Paz. Fondo de Cultura Económica, México; Madrid; Buenos Aires (1990).

Cesar, A. C. Inéditos e Dispersos. Editora Brasiliense, São Paulo (1985). 